\title{
Crystal Structure of $2^{\prime}, 3^{\prime}$-Di- $O$-Acetyl-5'-Deoxy-5-Fluorocytidine with $\mathrm{N}-\mathrm{H} \cdots(\mathrm{O}, \mathrm{F})$ Proton Donor Bifurcated and $(\mathrm{C}, \mathrm{N})-\mathrm{H} \cdots \mathrm{O}$ Bifurcated Acceptor Dual Three-Center Hydrogen Bond Configurations
}

\author{
Jerry P. Jasinski $\cdot$ Ray J. Butcher $\cdot$ L. Mallesha $\cdot$ K. N. Mohana $\cdot$ \\ H. S. Yathirajan · B. Narayana
}

Received: 14 August 2008/Accepted: 24 October 2008/Published online: 8 November 2008

(C) Springer Science+Business Media, LLC 2008

\begin{abstract}
The title compound, $\mathrm{C}_{13} \mathrm{H}_{16} \mathrm{O}_{6} \mathrm{~N}_{3} \mathrm{~F}$, features a central furan ring containing four carbon atom chiral centers with a 4-amino-5-fluoro-2-oxopyrimidine group, two acetyl groups and a methyl group bonded at the $2,3,4,5$ positions, each in an absolute $R$ configuration $(2 \mathrm{R}, 3 \mathrm{R}, 4 \mathrm{R}, 5 \mathrm{R})$. It crystallizes in the monoclinic space group $C 2$ with unit cell parameters $a=14.5341(3), b=7.26230(10), c=$ 16.2197(3) $\AA$, $\beta=116.607(2)^{\circ}, Z=4$. An extensive array of intra and intermolecular hydrogen bond interactions dominate crystal packing in the unit cell highlighted by a relatively rare three-center proton-bifurcated donor $\mathrm{N}-$ $\mathrm{H} \cdots(\mathrm{O}, \mathrm{F})$ hydrogen bond interaction in cooperation with a

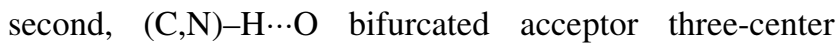
hydrogen bond in a supportive fashion. Additional weak $\mathrm{Cg} \pi$-ring intermolecular interactions between a fluorine atom and the 4-amino-5-fluoro-2-oxopyrimidine ring in concert with multiple donor and acceptor hydrogen bonds
\end{abstract}

Electronic supplementary material The online version of this article (doi:10.1007/s10870-008-9498-4) contains supplementary material, which is available to authorized users.

J. P. Jasinski ( $\square)$

Department of Chemistry, Keene State College, 229 Main Street,

Keene, NH 03435-2001, USA

e-mail: jjasinski@keene.edu

R. J. Butcher

Department of Chemistry, Howard University,

525 College Street NW, Washington, DC 20059, USA

L. Mallesha $\cdot$ K. N. Mohana $\cdot$ H. S. Yathirajan

Department of Studies in Chemistry, University of Mysore,

Manasagangotri, Mysore 570 006, India

B. Narayana

Department of Studies in Chemistry, Mangalore University,

Mangalagangotri 574 199, India significantly influence the bond distances, bond angles and torsion angles of the deoxy-5-fluorocytidine group. Comparison to a MOPAC computational calculation provides support to these observations.

Keywords Cytidine $\cdot$ Pyridine $\cdot$ Furan ·

Dual three-center hydrogen bond - Bifurcated · Donor .

Acceptor $\cdot$ R-chiral center $\cdot \pi$-Ring interactions

\section{Introduction}

The title compound, $\mathrm{C}_{13} \mathrm{H}_{16} \mathrm{O}_{6} \mathrm{~N}_{3} \mathrm{~F}$, (I), whose systematic name is $(2 R, 3 R, 4 R, 5 R)-2-(4-a m i n o-5-f l u o r o-2-o x o p y r i m i-$ din-1(2H)-yl)-5-methyl-tetrahydrofuran-3,4-diyl diacetate is a derivative of 5'-deoxy-5-fluorocytidine. It is an intermediate for the preparation of capecitabine, a prodrug of 5fluorouracil, which is the first and only orally administered fluoropyrimidine approved for the use as a second-line therapy of metastatic breast cancer, gastric, colorectal, bladder cancer and other solid malignancies [1-3]. Capecitabine is enzymatically converted to 5-fluorouracil in the tumor, where it inhibits DNA synthesis and slows growth of tumor tissue. Activation of capecitabine follows a pathway with three enzymatic steps and two intermediary metabolites, 5'-deoxy-5-fluorocytidine (5'-DFCR) and $5^{\prime}$ deoxy-5-fluorouridine ( $5^{\prime}$-DFUR), to form 5 -fluorouracil $\left[\begin{array}{ll}4,5 & 5\end{array} 2^{\prime}, 3^{\prime}\right.$-di- $O$-acetyl-5'-deoxy-5-fluorocytidine, the abbreviated name, was synthesized by glycosidation of 5-fluorocytosine with 1,2,3-tri- $O$-acetyl-5-deoxyribose with stannic tetrachloride in dichloromethane (at $15-20^{\circ} \mathrm{C}$ ) to form the title compound [6]. Crystal structures of similar compounds include cytidine [7], 2,3'-dideoxy-3'fluorocytidine [8] and 6-amino-3-( $\beta$-D-2-deoxy-erythrofuranosyl)-2-fluoropyridine [9]. In view of the importance 
of the title compound, the crystal structure of $\mathrm{C}_{13} \mathrm{H}_{16}$ $\mathrm{O}_{6} \mathrm{~N}_{3} \mathrm{~F}$, (I), is reported.

Method of Crystallization of $2^{\prime}, 3^{\prime}$-Di- $O$-Acetyl-5'Deoxy-5-Fluorocytidine

$2^{\prime}, 3^{\prime}$-Di- $O$-acetyl-5'-deoxy-5-fluorocytidine was obtained as a gift sample from Intermed Labs Private Ltd, Bangalore, India. Crystals suitable for single-crystal X-ray diffraction were grown from water by slow evaporation of solvent. The melting range was found to be $431-435 \mathrm{~K}$.

\section{Structure Determination and Refinement}

X-ray data for (I) was collected with an Oxford Diffraction Gemini R CCD area detector using CrysAlisPro software and graphite-monochromated $\mathrm{Cu}-\mathrm{K} \alpha(\lambda=1.54184 \AA)$ at 200(2) K. The structure was solved by direct methods using SHELXS97 [10] and all of the non-hydrogen atoms were refined anisotropically by full-matrix least-squares on $F^{2}$ using SHELXL97 [10]. The hydrogen atoms were placed in their calculated positions and included in the refinement using the riding model. The methyl hydrogen atoms were refined using HFIX137. An absorption correction was performed using CrysAlis RED and all calculations were performed using SHELXTL [11]. Crystal and experimental data for (I) are listed in Table 1. A scheme for the molecular structure of (I) is shown in Fig. 1. Bond lengths and bond angles are within expected ranges, Table 2 [12].

\section{Results and Discussion}

The title compound, also known as (2R,3R,4R,5R)-2-(4amino-5-fluoro-2-oxopyrimidin-1(2H)-yl)-5-methyl-tetrahydrofuran-3,4-diyl diacetate, consists of a central furan ring containing four carbon atom chiral centers with a 4amino-5-fluoro-2-oxopyrimidine group, two acetyl groups and a methyl group bonded at the $2,3,4,5$ positions, each in an absolute $\mathrm{R}$ configuration (2R,3R,4R,5R), respectively (Fig. 2). This was confirmed using $\mathrm{Cu}$ radiation to determine the absolute configuration during data collection. An extensive array of inter and intramolecular hydrogen bond interactions dominate crystal packing in the unit cell. Details of these hydrogen bond interactions are given in Table 3. A relatively rare three-center proton-bifurcated donor $\mathrm{N}-$ $\mathrm{H} \cdots(\mathrm{O}, \mathrm{F})$ hydrogen bond, focused on $\mathrm{H}(3 \mathrm{~B})$, highlights this intermolecular interaction in cooperation with a second, $(\mathrm{C}, \mathrm{N})-\mathrm{H} \cdots \mathrm{O}$ bifurcated acceptor three-center hydrogen bond focused on $\mathrm{O}(6)$. While numerous examples of three-center bonds formed by conventional strong hydrogen bonds exist
Table 1 Crystal and experimental data for (I)

\begin{tabular}{|c|c|}
\hline & (I) \\
\hline CCDC deposit no. & 698584 \\
\hline Formula & $\mathrm{C}_{13} \mathrm{H}_{16} \mathrm{FN}_{3} \mathrm{O}_{6}$ \\
\hline Formula weight & 329.29 \\
\hline Crystal color, habit & Colorless, chunk \\
\hline Crystal size (mm) & $0.55 \times 0.51 \times 0.42$ \\
\hline Crystal system & Monoclinic \\
\hline Space group, $Z$ & $C 2,4$ \\
\hline Temperature $(\mathrm{K})$ & $200(2)$ \\
\hline$a(\AA)$ & $14.5341(3)$ \\
\hline$b(\AA)$ & $7.26230(10)$ \\
\hline$c(\AA)$ & $16.2197(3)$ \\
\hline$\beta\left({ }^{\circ}\right)$ & $116.607(2)$ \\
\hline Volume, $\AA^{3}$ & $530.70(5)$ \\
\hline$F_{(000)}$ & 688 \\
\hline Absorption coefficient $\left(\mathrm{mm}^{-1}\right)$ & 1.051 \\
\hline$D_{\text {calc }}\left(\mathrm{Mg} \mathrm{m}^{-3}\right)$ & 1.429 \\
\hline No. of reflections $[I>2 \sigma(I)]$ & 2,826 \\
\hline $2 \theta_{\max }\left(^{\circ}\right)$ with $\mathrm{Cu}-\mathrm{K} \alpha$ & 146.78 \\
\hline$R, R_{\mathrm{w}}[I>2 \sigma(I)]$ & $0.0374,0.1030$ \\
\hline$R, R_{\mathrm{w}}$ [all data] & $0.0380,0.1032$ \\
\hline Restraints/parameters & $1 / 211$ \\
\hline Absolute structure parameter & $0.07(17)$ \\
\hline$(\Delta \rho)_{\max }\left(\mathrm{e} \AA^{-3}\right)$ & 0.634 \\
\hline$(\Delta \rho)_{\min }\left(\mathrm{e} \AA^{-3}\right)$ & -0.178 \\
\hline GOF on $F^{2}$ & 1.063 \\
\hline Measurement & $\begin{array}{l}\text { GEMINI (Oxford } \\
\text { Diffraction, 2007) }\end{array}$ \\
\hline Program system & CrysAlisPro \\
\hline Structure determination & SHELXS97 \\
\hline Refinement & $\begin{array}{c}\text { Full-matrix least-squares } \\
\text { on } F^{2} \text { (SHELXL97) }\end{array}$ \\
\hline
\end{tabular}

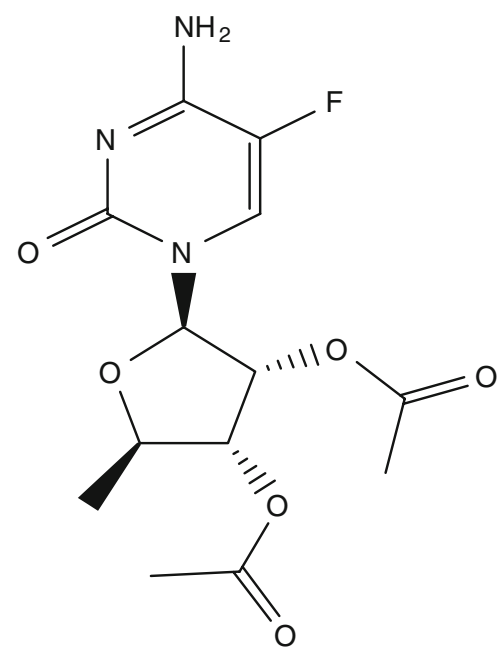

Fig. 1 Chemical structure of the title compound, $\mathrm{C}_{13} \mathrm{H}_{16} \mathrm{FN}_{3} \mathrm{O}_{6}$, (I) 
Table 2 Selected geometric parameters for (I) [^, $\left.{ }^{\circ}\right]$

\begin{tabular}{|c|c|c|c|c|c|}
\hline $\mathrm{O}(1)-\mathrm{C}(1)$ & $1.216(2)$ & {$[1.214]^{*}$} & $\mathrm{O}(2)-\mathrm{C}(5)$ & $1.411(3)$ & {$[1.356]^{*}$} \\
\hline $\mathrm{O}(3)-\mathrm{C}(7)$ & $1.440(2)$ & {$[1.425]^{*}$} & $\mathrm{O}(4)-\mathrm{C}(8)$ & $1.430(2)$ & {$[1.420]^{*}$} \\
\hline $\mathrm{O}(5)-\mathrm{C}(10)$ & $1.196(3)$ & {$[1.214]^{*}$} & $\mathrm{O}(6)-\mathrm{C}(12)$ & $1.195(3)$ & {$[1.214]^{*}$} \\
\hline $\mathrm{C}(2)-\mathrm{N}(2)$ & $1.330(2)$ & {$[1.329]^{*}$} & $\mathrm{C}(2)-\mathrm{N}(3)$ & $1.320(2)$ & {$[1.400]^{*}$} \\
\hline $\mathrm{O}(2)-\mathrm{C}(5)-\mathrm{N}(1)$ & $108.09(15)$ & {$[108.11]^{*}$} & $\mathrm{~N} 2(2)-\mathrm{C}(2)-\mathrm{N}(3)$ & $120.33(16)$ & {$[116.92]^{*}$} \\
\hline $\mathrm{O}(3)-\mathrm{C}(7)-\mathrm{C}(6)$ & $111.90(17)$ & {$[111.21]^{*}$} & $\mathrm{O}(4)-\mathrm{C}(8)-\mathrm{C}(5)$ & $108.47(15)$ & {$[106.27]^{*}$} \\
\hline $\mathrm{O}(3)-\mathrm{C}(10)-\mathrm{O}(5)$ & $122.72(19)$ & {$[119.88]^{*}$} & $\mathrm{O}(4)-\mathrm{C}(12)-\mathrm{O}(6)$ & $122.20(19)$ & {$[119.53]^{*}$} \\
\hline $\mathrm{O}(2)-\mathrm{C}(5)-\mathrm{N}(1)-\mathrm{C}(1)$ & $-118.47(19)$ & {$[-119.56]^{*}$} & $\mathrm{C}(1)-\mathrm{N}(2)-\mathrm{C}(2)-\mathrm{N}(3)$ & $-178.64(19)$ & {$[173.46]^{*}$} \\
\hline $\mathrm{C}(7)-\mathrm{O}(3)-\mathrm{C}(10)-\mathrm{O}(5)$ & $3.9(4)$ & {$[3.32]^{*}$} & $\mathrm{C}(8)-\mathrm{O}(4)-\mathrm{C}(12)-\mathrm{O}(6)$ & $-1.3(3)$ & {$[3.59]^{*}$} \\
\hline $\mathrm{F}-\mathrm{C}(3)-\mathrm{C}(2)-\mathrm{N}(3)$ & $2.4(3)$ & {$[6.43]^{*}$} & $\mathrm{C}(5)-\mathrm{N}(1)-\mathrm{C}(1)-\mathrm{O}(1)$ & $-2.8(3)$ & {$[-4.79]^{*}$} \\
\hline
\end{tabular}

* MOPAC computation results $\left[\AA{ }^{\circ},{ }^{\circ}[13]\right.$

Fig. 2 ORTEP drawings of (I) showing the atom numbering scheme of the asymmetric unit and $50 \%$ probability displacement ellipsoids of non$\mathrm{H}$ atoms

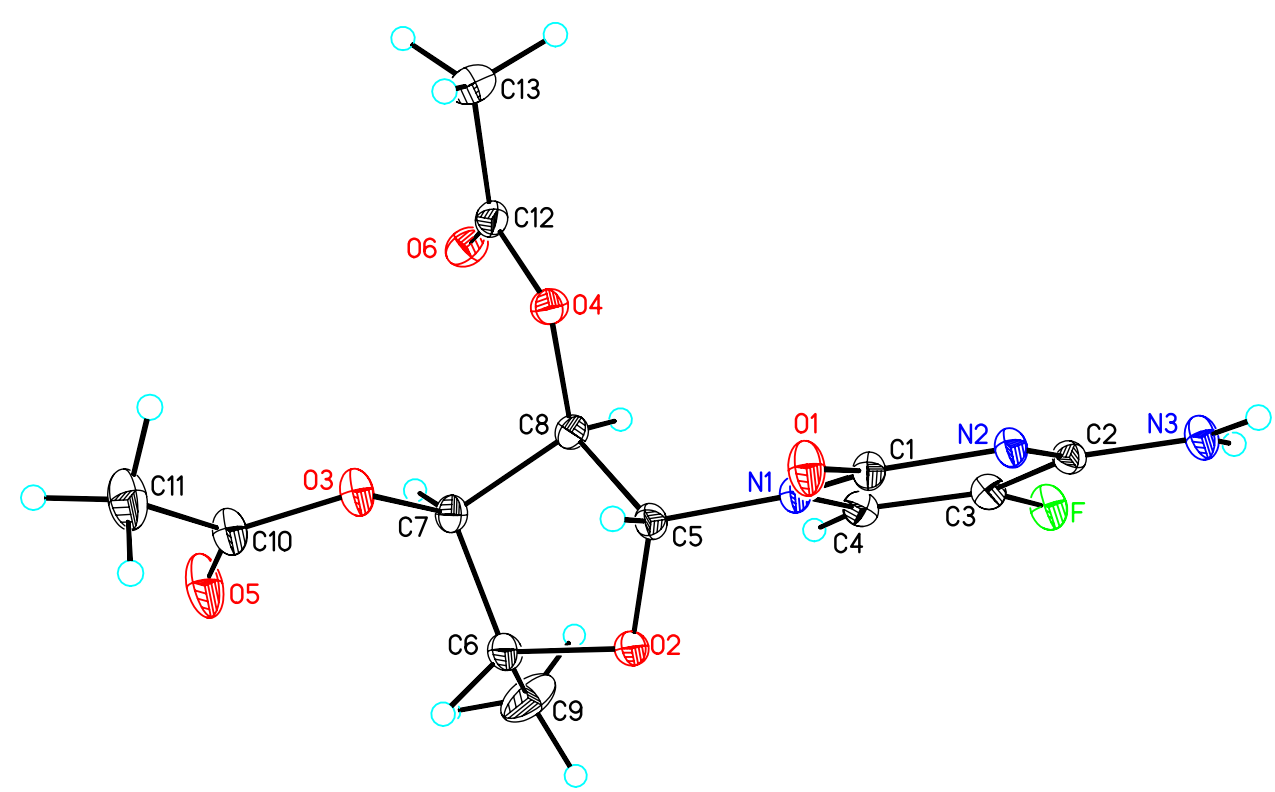

Table 3 Hydrogen bonds for (I) [ $\AA^{\circ}$ and ${ }^{\circ}$ ]

\begin{tabular}{lllll}
\hline $\mathrm{D}-\mathrm{H} \cdots \mathrm{A}$ & $\mathrm{d}(\mathrm{D}-\mathrm{H})$ & $\mathrm{d}(\mathrm{H} \cdots \mathrm{A})$ & $\mathrm{d}(\mathrm{D} \cdots \mathrm{A})$ & $<(\mathrm{DHA})$ \\
\hline $\mathrm{N}(3)-\mathrm{H}(3 \mathrm{~A}) \cdots \mathrm{N}(2) \# 1$ & 0.88 & 2.05 & $2.919(2)$ & 169.5 \\
$\mathrm{~N}(3)-\mathrm{H}(3 \mathrm{~B}) \cdots \mathrm{O}(6) \# 2$ & 0.88 & 2.42 & $3.147(2)$ & 139.9 \\
$\mathrm{~N}(3)-\mathrm{H}(3 \mathrm{~B}) \cdots \mathrm{O}(2) \# 3$ & 0.88 & 2.48 & $3.084(3)$ & 126.7 \\
$\mathrm{~N}(3)-\mathrm{H}(3 \mathrm{~B}) \cdots \mathrm{F}$ & 0.88 & 2.41 & $2.734(1)$ & 102.1 \\
$\mathrm{C}(5)-\mathrm{H}(5 \mathrm{~A}) \cdots \mathrm{O}(1)$ & 1.00 & 2.30 & $2.747(7)$ & 106.1 \\
$\mathrm{C}(6)-\mathrm{H}(6 \mathrm{~A}) \cdots \mathrm{O}(6) \# 4$ & 1.00 & 2.47 & $3.159(3)$ & 125.4 \\
$\mathrm{C}(11)-\mathrm{H}(11 \mathrm{~A}) \cdots \mathrm{O}(6) \# 5$ & 0.98 & 2.57 & $3.467(3)$ & 151.4
\end{tabular}

Symmetry transformations used to generate equivalent atoms: \#1 $-x+2, y,-z+1 ; \# 2-x+3 / 2, y+1 / 2,-z+1 ; \# 3-x+3 / 2$, $y-1 / 2,-z+1$; \#4 $x, y+1, z ; \# 5-x+1 / 2, y+1 / 2,-z$

[14], the bifurcation of weak interactions, such as between a weak donor and strong acceptors, are not as well characterized. In (I), the mean plane of the furan ring is twisted $83.7(1)^{\circ}$ with that of the pyrimidine ring. The torsion angles of the $\mathrm{O}(1), \mathrm{F}$ and $\mathrm{N}(3)$ substituent atoms are twisted slightly out of the plane of the pyrimidine ring with $\mathrm{O}(1) / \mathrm{C}(1) / \mathrm{N}(2) /$ $\mathrm{C}(2), \quad \mathrm{F} / \mathrm{C}(3) / \mathrm{C}(2) / \mathrm{N}(3)$ and $\mathrm{C}(1) / \mathrm{N}(2) / \mathrm{C}(2) / \mathrm{N}(3)$ torsion angles of $177.2(2)^{\circ}, 2.4(3)^{\circ}$ and $-178.64(19)^{\circ}$, respectively. Selected geometric parameters for (I) are listed in Table 2. The crystal structure is held together by intermolecular $\mathrm{N}-\mathrm{H} \cdots \mathrm{N}[\# 1-x+2, y,-z+1: 2.919(2) \AA], \mathrm{N}-\mathrm{H} \cdots \mathrm{O}[\# 2$ $-x+3 / 2, y+1 / 2,-z+1: 3.147(2) \AA],[\# 3-x+3 / 2$, $y-1 / 2,-z+1: 3.084(3) \AA]$ and $\mathrm{C}-\mathrm{H} \cdots \mathrm{O}[\# 4 x, y+1$, $z: 3.159(3) \AA],[\# 5-x+1 / 2, y+1 / 2,-z: 3.467(3) \AA]$ interactions as well as by weak $\mathrm{C}(3)-\mathrm{F} \cdots \mathrm{Cg} 2 \pi$-ring interactions $[\mathrm{C}(3) \cdots \mathrm{Cg}=3.499(8) \AA, \mathrm{F} \cdots \mathrm{Cg}=3.095(9) \AA$, $\mathrm{C}(3)-\mathrm{F}-\mathrm{Cg}=96.0(1)^{\circ}, \quad(\mathrm{C}(3): 3 / 2-x,-1 / 2+y, 1-z)$, $\mathrm{Cg} 2=$ center of gravity of $\mathrm{N}(1) / \mathrm{C}(1) / \mathrm{N}(2) / \mathrm{C}(2) / \mathrm{C}(3) / \mathrm{C}(4)]$. Intramolecular $\mathrm{N}(3)-\mathrm{H}(3 \mathrm{~B}) \cdots \mathrm{F}$ and $\mathrm{C}(5)-\mathrm{H}(5 \mathrm{~A}) \cdots \mathrm{O}(1)$ hydrogen bonds exist and both form $\mathrm{R}(5)$ closed patterns $(\mathrm{N}(3) / \mathrm{C}(2) / \mathrm{C}(3) / \mathrm{F} \cdots \mathrm{H}(3 \mathrm{~B})$ and $\mathrm{C}(5) / \mathrm{N}(1) / \mathrm{C}(1) / \mathrm{O}(1) \cdots \mathrm{H}(5 \mathrm{~A}))$ [15]. Intermolecular $\mathrm{N}(3)-\mathrm{H}(3 \mathrm{~B}) \cdots \mathrm{O}(6)[\# 3-x+3 / 2, y-1 /$ $2,-z+1]$ and $\mathrm{C}(6)-\mathrm{H}(6 \mathrm{~A}) \cdots \mathrm{O}(6)[\# 4 x, y+1, z]$ hydrogen bonds link the molecules into an infinite one-dimensional 
Fig. 3 The molecular packing for (I) viewed down the $a$ axis. Dashed lines indicate intermolecular $\mathrm{C}(6)$ $\mathrm{H}(6 \mathrm{~A}) \cdots \mathrm{O}(6)$ and $\mathrm{N}(3)-$ $\mathrm{H}(3 \mathrm{~B}) \cdots \mathrm{O}(6)$ hydrogen bonds linking the molecules into an infinite one-dimensional chain extending along the $b$ axis of the unit cell

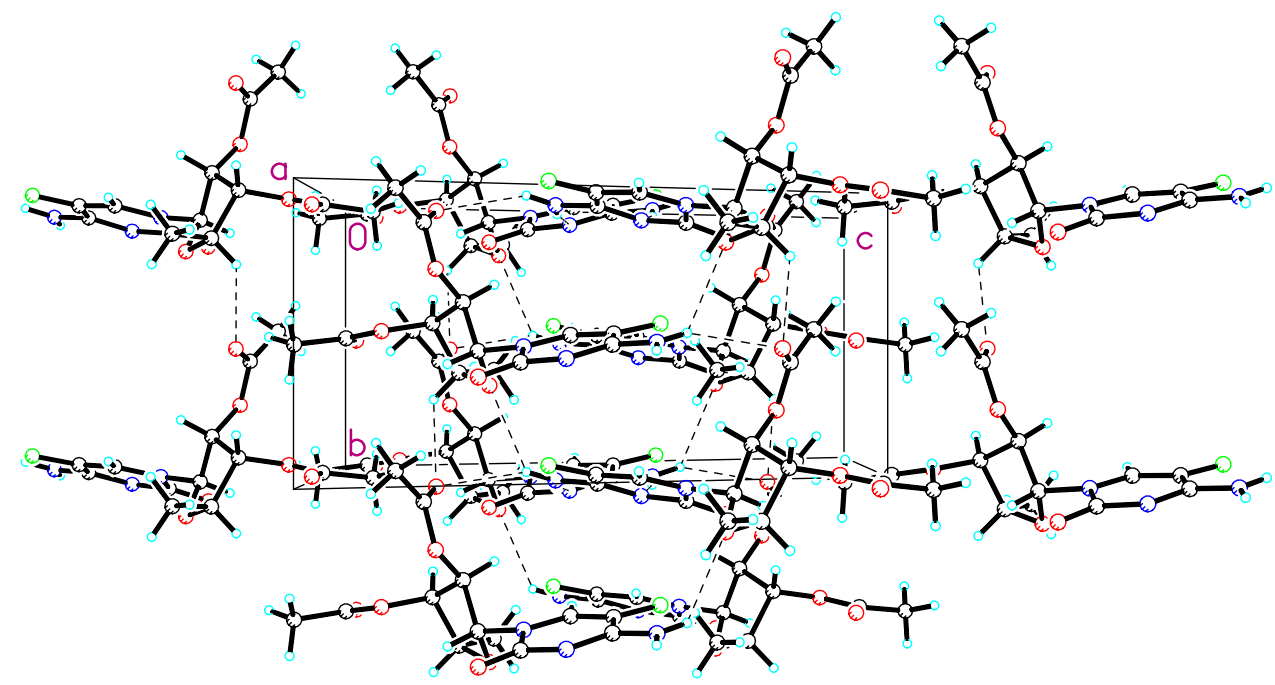

chain extending along the $b$ axis of the unit cell (Fig. 3). The intramolecular $\mathrm{N}(3)-\mathrm{H}(3 \mathrm{~B}) \cdots \mathrm{F}$ and intermolecular $\mathrm{N}(3)-$ $\mathrm{H}(3 \mathrm{~B}) \cdots \mathrm{O}(2), \quad \mathrm{N}(3)-\mathrm{H}(3 \mathrm{~B}) \cdots \mathrm{O}(6)$ interactions collectively form the bifurcated three-center hydrogen bond configuration focused around the $\mathrm{H}(3 \mathrm{~B})$ atom which is at the center of three participating donor $(\mathrm{H}(3 \mathrm{~B}))$ and acceptor $(\mathrm{F}, \mathrm{O}(2), \mathrm{O}(6))$ atoms and somewhat indistinguishable from each other (Fig. 4). The sum of the angles around $\mathrm{H}(3 \mathrm{~B})$ equals $369^{\circ}$, which is slighter greater than the ideal value of $360^{\circ}$ for $\mathrm{C}-$ $\mathrm{H} \cdots \mathrm{C}, \mathrm{C}-\mathrm{H} \cdots \mathrm{O}$ molecular systems [16]. In addition, the

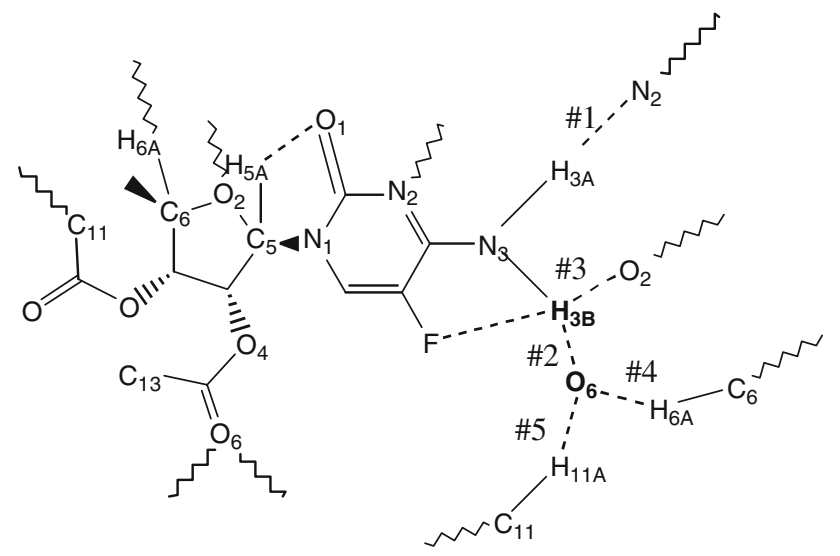

Fig. 4 Hydrogen bonding scheme of the title compound, $\mathrm{C}_{13} \mathrm{H}_{16} \mathrm{FN}_{3} \mathrm{O}_{6}$, (I), showing the intramolecular $\mathrm{N}(3)-\mathrm{H}(3 \mathrm{~B}) \cdots \mathrm{F}$ and intermolecular $\mathrm{N}(3)-\mathrm{H}(3 \mathrm{~B}) \cdots \mathrm{O}(2), \mathrm{N}(3)-\mathrm{H}(3 \mathrm{~B}) \cdots \mathrm{O}(6)$ interactions that collectively form the bifurcated three-center hydrogen bond configuration focused around the $\mathrm{H}(3 \mathrm{~B})$ atom which is at the center of three participating donor $(\mathrm{H}(3 \mathrm{~B}))$ and acceptor $(\mathrm{F}, \mathrm{O}(2), \mathrm{O}(6))$ atoms. Also shown are the intermolecular $\mathrm{N}(3)-\mathrm{H}(3 \mathrm{~B}) \cdots \mathrm{O}(6), \mathrm{C}(6)-$ $\mathrm{H}(6 \mathrm{~A}) \cdots \mathrm{O}(6)$ and $\mathrm{C}(11)-\mathrm{H}(11 \mathrm{~A}) \cdots \mathrm{O}(6)$ interactions which collectively form a second three-center hydrogen bond configuration focused around the $\mathrm{O}(6)$ acceptor atom which is at the center of three participating donor $(\mathrm{H}(3 \mathrm{~B}), \mathrm{H}(6 \mathrm{~A}), \mathrm{H}(11 \mathrm{~A}))$ atoms. Additional intramolecular $(\mathrm{C}(5)-\mathrm{H}(5 \mathrm{~A}) \cdots \mathrm{O}(1))$ and intermolecular $(\mathrm{N}(3)-$ $\mathrm{H}(3 \mathrm{~A}) \cdots \mathrm{N}(2)$ hydrogen bonds are also shown intermolecular $\mathrm{N}(3)-\mathrm{H}(3 \mathrm{~B}) \cdots \mathrm{O}(6), \mathrm{C}(6)-\mathrm{H}(6 \mathrm{~A}) \cdots \mathrm{O}(6)$ and $\mathrm{C}(11)-\mathrm{H}(11 \mathrm{~A}) \cdots \mathrm{O}(6)$ interactions collectively form a second three-center hydrogen bond configuration focused around the $\mathrm{O}(6)$ acceptor atom which is at the center of three participating donor $(\mathrm{H}(3 \mathrm{~B}), \mathrm{H}(6 \mathrm{~A}), \mathrm{H}(11 \mathrm{~A}))$ atoms. The angle between the mean planes of the $\mathrm{R}(5)$ intramolecular component $(\mathrm{N}(3) / \mathrm{C}(2) / \mathrm{C}(3) / \mathrm{F} \cdots \mathrm{H}(3 \mathrm{~B}))$ and the intermolecular $\mathrm{O}(2) / \mathrm{C}(6) / \mathrm{H}(6 \mathrm{~A}) / \mathrm{O}(6) \cdots \mathrm{H}(3 \mathrm{~B})$ component of the two threecenter bonds connected through the $\mathrm{H}(3 \mathrm{~B})$ pivot atom common to both components is $87.3(4)^{\circ}$ indicating a side-on intramolecular component nearly perpendicular and head-on to an intermolecular component This arrangement is similar to that observed in related similar $\mathrm{C}-\mathrm{H} \cdots(\mathrm{O}, \mathrm{O})$ bifurcated three-center bond interactions [17].

A MOPAC AM1 calculation was performed on (I) with WebMO Pro **[13], to examine the effects of these multiple intra and intermolecular hydrogen bond interactions on the crystal packing environment of the $\mathrm{C}_{13} \mathrm{H}_{16} \mathrm{O}_{6} \mathrm{~N}_{3} \mathrm{~F}$ molecule. The greatest difference in bond lengths and bond angles observed in the crystal structure versus that found from the AM1 calculation $[\mathrm{O}(2)-\mathrm{C}(5)$ : 1.411(3) $\AA$ vs. $1.356 \AA$; O(6)-C(12): $1.195(3) \AA$ vs. $1.214 \AA, \mathrm{C}(2)-\mathrm{N}(3)$ : $1.320(2) \AA$ vs. $1.400 \AA$ and $\mathrm{N}(2)-\mathrm{C}(2)-\mathrm{N}(3): 120.33(16)^{\circ}$ vs. $116.92^{\circ}, \mathrm{O}(4)-\mathrm{C}(8)-\mathrm{C}(5) \quad 108.47(15)^{\circ}$ vs. $106.27^{\circ}$, $\mathrm{O}(3)-\mathrm{C}(10)-\mathrm{O}(5) 122.72(19)^{\circ}$ vs. $119.88^{\circ}, \mathrm{O}(4)-\mathrm{C}(12)-$ $\mathrm{O}(6) 122.20(19)^{\circ}$ vs. $119.53^{\circ}$ ] indicate that the central atoms in the two three-centered donor and acceptor bifurcated hydrogen bonded species $(\mathrm{H}(3 \mathrm{~B})$ \& $\mathrm{O}(6))$ play a prominent role in the crystal packing with their multiple intra and intermolecular interactions which may more accurately characterized as hydrogen bridges [18, 19] which help stabilize crystal packing (Table 2). Desiraju [20] has recently suggested that the roles of these types of interactions in crystal packing may be described in a more qualitative manner and categorized as innocuous, 
supportive and intrusive. With regard to the geometry and directionality of the interactions in this crystalline system they would most likely be categorized as a supportive type of interaction. It is clear from the MOPAC computational calculations that the distortions in the bond distances, bond angles and torsion angles of those atoms more directly involved in the multiple hydrogen bond interaction sites are significantly influenced by the strength and number of singular and dual bifurcated hydrogen bond bridges and $\pi$ ring interactions that are observed.

\section{Supporting Information Available}

X-ray crystallographic files, in Cif format, for the structure determinations of (I) (698584) has been deposited with the Cambridge Crystallographic Date Center, CCDC: 26091. Copies of this information may be obtained free of charge from the Director, CCDC, 12 Union Road, Cambridge, CB2 1EZ (fax: +44-1223-336033; email: deposit@ccdc. cam.ac.uk or at: http://www.ccdc.cam.ac.uk).

Acknowledgments LM thanks the University of Mysore for use of their research facilities. RJB acknowledges the NSF MRI program (grant No. CHE-0619278) for funds to purchase the X-ray diffractometer.

\section{References}

1. McDonald F, Miles D (2003) Int J Clin Pract 57:530-534

2. McGavin JK, Goa KL (2001) Drugs 61:2309-2326. doi: 10.2165/00003495-200161150-00015

3. Wenzel C, Mader RM, Steger GG, Pluschnig U, Kornek GV, Scheithauer W, Locker GJ (2003) Anticancer Drugs 14:119-123. doi:10.1097/00001813-200302000-00005
4. Shimma N, Umeda I, Arasaki M, Murasaki C, Masubuchi K, Kohchi Y, Miwa M, Ura M, Sawada N, Tahara H, Kuruma I, Horii I, Ishitsuka H (2000) Bioorg Med Chem 8:1697-1706. doi: 10.1016/S0968-0896(00)00087-0

5. Hattori K, Kohchi Y, Oikawa N, Suda H, Ura M, Ishikawa T, Miwa M, Endoh M, Eda H, Tanimura H, Kawashima A, Horii I, Ishitsuka H, Shimma N (2003) Bioorg Med Chem Lett 13:867872. doi:10.1016/S0960-894X(02)01082-X

6. Xiangshu F, Wang J-Q, Miller KD, Sledg GW, Hutchins GD, Zheng Q-H (2004) Nucl Med Biol 31:1033-1041. doi: 10.1016/j.nucmedbio.2004.02.006

7. Furberg S, Peterson CS, Rømming C (1965) Acta Crystallogr 18:313-320. doi:10.1107/S0365110X65000749

8. De Winter HL, Blaton NM, Peeters OM, De Ranter CJ, Van Aerschot A, Herdewijn P (1991) Acta Crystallogr C47:832-835

9. Sun Z, Lo W, McLaughlin LW (2006) Acta Crystallogr E62:o1437-o1439

10. Sheldrick GM (1997) SHELXS97, SHELXL97. University of Göttingen, Germany

11. Bruker (2000) SHELXTL Version 6.10. Bruker AXS Inc., Madison

12. Allen FH, Kennard O, Watson DG, Brammer L, Orpen AG, Taylor RJ (1987) Chem Soc Perkin Trans 2:S1-S19. doi: $10.1039 / \mathrm{p} 298700000 \mathrm{~s} 1$

13. AM1 approximation together with the Hartree-Fock closed-shell restricted wavefunction was used and minimizations were terminated at an r.m.s. gradient of less than $0.01 \mathrm{~kJ} \mathrm{~mol}^{-1} \AA^{-1}$. Schmidt JR, Polik WF (2007) WebMO Pro, version 8.0.010e. WebMO, LLC, Holland. Available from http://www.webmo.net

14. Jeffrey GR, Saenger W (1991) Hydrogen bonding in biological structures. Springer, New York

15. Bernstein J, Davis RE, Shimini L, Chang N-L (1995) Angew Chem Int Ed Engl 34:1555-1673. doi:10.1002/anie.199515551

16. Parthasarathy R (1969) Acta Crystallogr B25:509-518

17. Rathore RS, Narasimhamurthy T, Vijay T, Yathirajan HS, Nagaraja P (2006) Acta Crystallogr C62:o36-038. doi: 10.1107/S0108270105038114

18. Desiraju GR (2002) Acc Chem Res 35:565-573. doi: 10.1021/ar010054t

19. Desiraju GR (2005) Curr Sci 88:374-380

20. Desiraju GR (2005) Chem Commun (Camb) 2995-3001. doi: $10.1039 / \mathrm{b} 504372 \mathrm{~g}$ 